\title{
Effect of vegetation on cutaneous leishmaniasis in Paraná, Brazil
}

\author{
Helen Aline Melo ${ }^{1 /+}$, Diogo Francisco Rossoni ${ }^{2}$, Ueslei Teodoro ${ }^{1}$ \\ ${ }^{1}$ Universidade Estadual de Maringá, Programa de Pós-Graduação em Ciências da Saúde, Maringá, PR, Brasil \\ ${ }^{2}$ Universidade Estadual de Maringá, Departamento de Estatística, Maringá, PR, Brasil
}

BACKGROUND Cutaneous leishmaniasis (CL) is endemic in the state of Paraná, Brazil.

OBJECTIVE This study aimed at analysing the influence of the remaining native vegetation on the prevalence of CL in Paraná.

METHODS Global testing was used for spatial autocorrelation along with simultaneous autoregressive model (SAR). The regression was based on the CL coefficient (cases/100,000 inhabitants) as a function of the percentage of natural vegetation cover, altitude, total number of cases, and spatial density (SD) per $\mathrm{km}^{2}$; the location data of the Paraná state municipalities and the detection coefficient (DC) (cases/100,000 inhabitants) of autochthonous cases of CL were obtained from the SINAN in 2012 and 2016. Data on the remaining forests were collected from the Fundação SOS Mata Atlântica and Instituto Nacional de Pesquisas Espaciais.

FINDINGS The spatial regression of DC revealed statistical significance for $\mathrm{SD}(\mathrm{Z}=24.1359, \mathrm{p}<0.05,2012-2013 ; Z=24.0817, \mathrm{p}$ $<0.05,2013-2014 ; \mathrm{Z}=33.4824, \mathrm{p}<0.05,2014-2015$; and $\mathrm{Z}=27.1515, \mathrm{p}<0.05,2015-2016$.

CONCLUSIONS CL cases are reported in areas with native vegetation, such as in riparian forests. However, vegetation is not the only variable that influences the incidence of CL.

Key words: cutaneous leishmaniasis - zoonoses - environmental health - spatial analysis - spatial regression

The prevalence of cutaneous leishmaniasis (CL) is reported in 97 countries, including America and those in Europe, Africa, and Asia, with 0.7-1.3 million new cases registered annually (WHO 2017). This disease is one of the six most severe infectious diseases worldwide due to its high detection coefficient (DC) and capability to cause deformations in patients (MS 2016). In Brazil, from 1993 to 2016, the annual average number of CL cases was 22,140, with a DC of 9.8 cases/100,000 inhabitants (MS 2016). CL is endemic in Brazil. In the early 1980s, autochthon cases were reported in 19 states. Moreover, in 2003, there are registered cases in every state of the country (MS 2016).

According to Luz et al. (2000), between 1930 and 1950, CL reached epidemic proportions to the north of Paraná during the colonisation period due to the replacement of native vegetation with coffee plantations. In the 1950s, the incidence of this zoonotic disease rapidly decreased due to the indirect effect of the malaria control campaigns about chlorinated insecticides (Luz et al. 2000). However, since 1980, CL has been endemic in Paraná (Lima et al. 2002). From 1980 to 2016, 16,464 cases were reported in the northern, western, and southwestern parts of the state (MS 2017).

In the state of Paraná, the natural life cycle of Leishmania is significantly associated with the natural forest areas that are close to the traditional agricultural production areas. The number of CL cases is highest in areas located in the basins of the Ivaí and Pirapó rivers, where there are native residual forests (Lima et al. 2002, Mon-

doi: 10.1590/0074-02760170505

+Corresponding author: helen_alinemelo@hotmail.com

Received 17 November 2017

Accepted 13 April 2018 teiro et al. 2008, Monteiro et al. 2009) as well as in the urban areas of Maringá (Teodoro et al. 1998, Lima et al. 2002) and Cianorte (Lima et al. 2002). Despite the substitution of native forest vegetation for coffee, soybean, corn, cotton, and pasture crops, the persistent incidence of CL in Paraná is the result of the successful adaptation of the vectors and reservoirs of parasites in the areas affected by human activities (Lima et al. 2002).

Data on the occupation of agrarian and urban spaces, vegetation cover, and the geographical distribution of CL allow the formulation of hypotheses and the planning of health services that control CL, particularly its vector (King et al. 2004, Monteiro et al. 2008). Therefore, the factors that influence the geographical distribution of CL were used in our statistical analysis using georeferencing, which will be extremely valuable in the planning of health initiatives (Medronho et al. 2003, Eisen and Eisen 2008, Magalhães 2012). The present study aimed at evaluating the association between CL and residual native vegetation, which is considered a risk factor for the prevalence of the disease, in the state of Paraná. Statistical analysis using georeferencing was carried out to assess this association.

\section{MATERIALS AND METHODS}

Description of the state of Paraná - The state of Paraná is in southern Brazil (22 $2^{\circ} 30^{\prime} 58^{\prime \prime}$ and 28 43'00' S; $48^{\circ} 05^{\prime} 37^{\prime \prime}$ and $\left.54^{\circ} 37^{\prime} 08^{\prime \prime} \mathrm{W}\right)$, with an area of 199,307.945 $\mathrm{km}^{2}$. It has 399 municipalities that are distributed across 10 macro-regions and 39 micro-regions. During the study period, the estimated population was $10,997,465$, with a demographic density of 55.18 inhabitants $/ \mathrm{km}$ and a human development index of 0.749 (IBGE 2010, IBGE 2016).

Paraná has three distinct climates according to the Köppen climate classification system. First, the tropical rainforest climate (megathermal, Af), which is restricted to the coastal strip, has an average temperature higher 


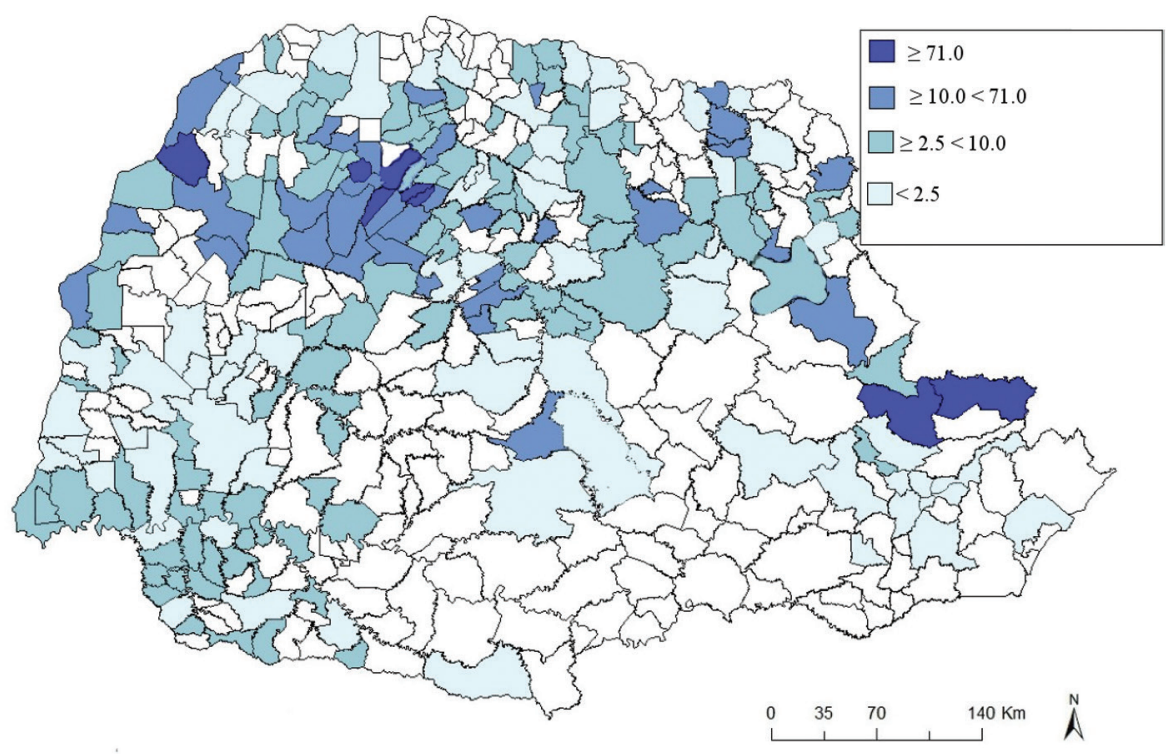

Fig. 1: distribution of cutaneous leishmaniosis cases in terms of detection coefficient (cases per 100,000 inhabitants) in the state of Paraná, Brazil, from 2012 to 2016.

than $18^{\circ} \mathrm{C}$. Second, the humid subtropical climate (mesothermal, $\mathrm{Cfa}$ ), which is the most common type of climate in the state, has an average temperature of $22^{\circ} \mathrm{C}$ and can reach up to $40^{\circ} \mathrm{C}$ in the North, Central-West, and the Ribeira River Valley regions during their warmest months. Meanwhile, its lowest average temperature is $18^{\circ} \mathrm{C}$. Finally, the temperature oceanic climate (mesothermal, $\mathrm{Cfb}$ ) has an average temperature of $18-22^{\circ} \mathrm{C}$ (IAPAR 2002).

Data collection - To analyse the influence of native vegetation on autochthonous cases of $\mathrm{CL}$ in the state of Paraná, data were obtained from the Sistema de Informação de Agravos de Notificação (SINAN; Information System for Notifiable Diseases) from January 2012 to December 2016. For the DC (autochthonous cases per 100,000 inhabitants), spatial density (SD) (cases per $\mathrm{km}^{2}$ ), altitude, and territorial area, the population and territorial data of each municipality were used based on the Instituto Brasileiro de Geografia e Estatística (Brazilian Institute for Geography and Statistics; IBGE 2010, IBGE 2016). Moreover, data on the residual native vegetation, river basins, and phytogeographical regions were provided by Fundação SOS Mata Atlântica (SOS Mata Atlântica Foundation) and Instituto Nacional de Pesquisas Espaciais (National Institute of Space Research, INPE; SOSMA 2017). Information on gender, age, clinical form, and the proportion of patients with CL who were cured was collected. In the present study, we focused on municipalities with SD values $\geq 0.010$, which were considered as highrisk areas for disease transmission.

Geographical and statistical analyses - Geographical analysis was performed using the simultaneous autoregressive model (SAR) model (Bivand et al. 2008) that calculates the regression of values from several areas to model spatial dependence. Regression was based on the coefficient of the detection of CL (cases/100,000 inhabit-
TABLE I

Demographic and clinical characteristics of cutaneous leishmaniasis (CL) cases in the state of Paraná, Brazil, from 2012 to 2016 obtained using the chi-squared test

\begin{tabular}{|c|c|c|c|}
\hline Characteristics of the participants & $\mathrm{n}$ & $\%$ & $\mathrm{p}$-value \\
\hline Sex & & & $<0.001$ \\
\hline Male & 1,187 & 74.19 & \\
\hline Female & 413 & 25.81 & \\
\hline Age group (years) & & & $<0.001$ \\
\hline$>1$ & 10 & 0.63 & \\
\hline $1-4$ & 8 & 0.50 & \\
\hline $5-9$ & 32 & 2.00 & \\
\hline $10-14$ & 54 & 3.38 & \\
\hline $15-19$ & 86 & 5.38 & \\
\hline $20-39$ & 500 & 31.25 & \\
\hline $40-59$ & 561 & 35.06 & \\
\hline $60-64$ & 106 & 6.63 & \\
\hline $65-69$ & 102 & 6.38 & \\
\hline $70-79$ & 107 & 6.69 & \\
\hline$\geq 80$ & 34 & 2.13 & \\
\hline Clinical form & & & $<0.001$ \\
\hline Cutaneous & 1,445 & 90.31 & \\
\hline Mucocutaneous & 154 & 9.61 & \\
\hline Not informed & 1 & 0.06 & \\
\hline Case outcome & & & $<0.001$ \\
\hline Clinical cure & 1,029 & 64.31 & \\
\hline Abandonment of treatment & 17 & 1.06 & \\
\hline Death related to CL & 5 & 0.31 & \\
\hline Death from other causes & 26 & 1.63 & \\
\hline Transfer & 14 & 0.88 & \\
\hline Change of diagnosis & 2 & 1.44 & \\
\hline Not informed & 486 & 30.38 & \\
\hline
\end{tabular}


ants) as a function of the percentage of natural vegetation, altitude, the total number of cases, and SD (cases per $\mathrm{km}^{2}$ ). This result shows that the error is modeled based on its dependence on other errors. It is defined as

$$
e_{i}=\sum_{i=1}^{m} b_{i j} e_{i}+\varepsilon_{i},
$$

where $b_{i j}$ represents the values of spatial dependence between the areas and $\varepsilon_{i}$ represents the residual error that is considered independent and identically distributed according to normal with zero mean and constant variance.

All statistical analyses were performed with R software (environment), with 95\% confidence interval (CI). The collinearity between variables was evaluated, and the variables that were unstable were not used in the study (Development Core Team 2014).

\section{RESULTS}

From 2012 to 2016, there were 1600 (54.39\%) reported cases of CL across 217 municipalities in the state of Paraná (Fig. 1, Table I). Among these, 8 (3.69\%), 37 (17.05\%), 102 $(47.00 \%)$, and $70(32.26 \%)$ municipalities had a DC of $\geq$ $71.0, \geq 10.0<71.0, \geq 2.5<10.0$, and $<2.5$, respectively. The following municipalities had the highest number of cases: Cianorte, Umuarama, Londrina, Jussara, Cerro Azul, and Maringá. Approximately $30.13 \%$ of CL cases were reported in these municipalities in 2012 and 2016. The following municipalities had the highest DC: Ivatuba, Jussara, São Jorge do Ivaí, Adrianópolis, Doutor Camargo, and Japurá (Table II), whereas 39 other municipalities had a DC $\geq$ 10.0 , which include areas with high or extremely high CL transmission potential. Based on the analysis, municipalities, such as Ivatuba, Jussara, Japurá, Doutor Camargo, and Cianorte, had a significant SD (Table II).
Data on the native vegetation in the state of Paraná from 2012 to 2016 revealed that only $11.6 \%$ of the original vegetation cover remains (Figs 2-3). Spatial regression of DC revealed statistical significance only for SD (cases per km $\left.{ }^{2}\right)(Z=24.1359, \mathrm{p}<0.05,2012-2013 ; \mathrm{Z}=$ 24.0817, $\mathrm{p}<0.05,2013-2014 ; \mathrm{Z}=33.4824, \mathrm{p}<0.05$, 20142015; and $Z=27.1515, p<0.05,2015-2016)$ and the total number of cases $(Z=2.1146, p<0.05,2015-2016)$. Meanwhile, the values of other variables were as follows: for altitude, $\mathrm{Z}=-0.4840, \mathrm{p}>0.05,2012-2013 ; \mathrm{Z}=-0.9054$, $\mathrm{p}>0.05,2013-2014 ; Z=-1.5980, \mathrm{p}>0.05,2014-2015 ; \mathrm{Z}$ $=-1.6127, p>0.05,2015-2016$; for the total number of cases, $\mathrm{Z}=-1.2357, \mathrm{p}>0.05,2012-2013 ; \mathrm{Z}=1.1118, \mathrm{p}>$ 0.05, 2013-2014; $Z=0.1938, p>0.05,2014-2015$.

\section{DISCUSSION}

Despite the significance of CL based on the expressive number of cases reported annually and its occurrence in all the states of Brazil, this disease continues to be neglected (Monteiro et al. 2008, MS 2016). Moreover, regardless of the increasing number of human interventions, the natural foci of CL are still found in rural and urban areas during the recent and past colonization (Lima et al. 2002, MS 2016).

Based on the regression analysis, a statistically significant difference $(p<0.05)$ was observed in terms of the SD of Ivatuba, Cianorte, Corumbataí do Sul, Doutor Camargo, Japurá, Jussara, Lunardelli, Mandaguaçu, Maringá, Moreira Sale, Paraíso do Norte, São Tomé, Terra Boa, Tuneiras do Oeste, and Umuarama, all of which are located in the CL generation hub, referred to as Ivaí-Pirapó hub by Monteiro et al. (2009). The semideciduous forest areas in these municipalities are represented by the fragments of natural vegetation cover
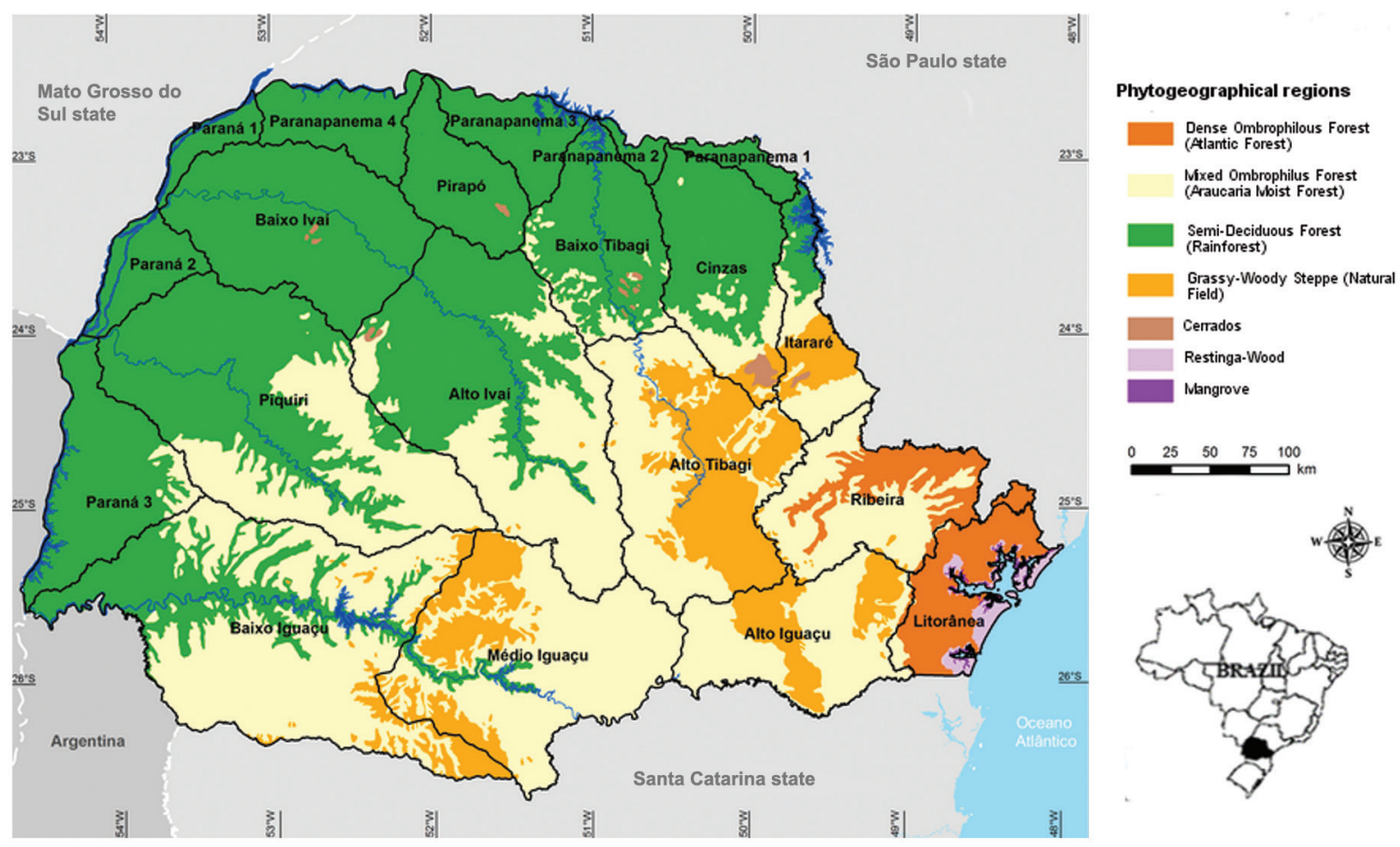

Fig. 2: phytogeographical regions and river basins in the state of Paraná, Brazil (Maack 1968). 
TABLE II

Number, spatial density (SD), and detection coefficient (DC) of cutaneous leishmaniasis (CL) cases as well as natural vegetation covers in the municipalities with $\mathrm{SD} \geq 0.010$ in the state of Paraná, Brazil, from 2012 to 2016

\begin{tabular}{|c|c|c|c|c|c|c|c|c|c|}
\hline Municipality & $\mathrm{NC}$ & SD & DC & V & Municipality & $\mathrm{NC}$ & SD & DC & V \\
\hline Abatiá & 6 & 0.026 & 15.43 & 2 & Mandaguaçu & 13 & 0.044 & 12.20 & 4 \\
\hline Adrianópolis & 37 & 0.027 & 117.29 & 36 & Mandaguari & 5 & 0.015 & 2.95 & 7 \\
\hline Altônia & 10 & 0.015 & 9.32 & 23 & Maringá & 59 & 0.121 & 3.02 & 3 \\
\hline Âmpere & 4 & 0.013 & 4.37 & 4 & Marmeleiro & 7 & 0.018 & 9.78 & 6 \\
\hline Apucarana & 14 & 0.025 & 2.18 & 10 & Miraselva & 2 & 0.022 & 21.37 & 7 \\
\hline Arapongas & 10 & 0.026 & 1.76 & 8 & Moreira Sales & 4 & 0.011 & 6.33 & 2 \\
\hline Araruna & 12 & 0.024 & 17.32 & 4 & Nova Esperança & 7 & 0.017 & 5.08 & 3 \\
\hline Bandeirantes & 43 & 0.097 & 26.54 & 3 & Nova Olímpia & 2 & 0.015 & 7.00 & 4 \\
\hline Bela Vista do Paraíso & 3 & 0.012 & 3.88 & 9 & Paiçandu & 10 & 0.058 & 5.17 & 2 \\
\hline Bom Sucesso & 4 & 0.012 & 11.67 & 12 & Paraíso do Norte & 9 & 0.044 & 14.07 & 3 \\
\hline Cambé & 13 & 0.026 & 2.54 & 5 & Peabiru & 7 & 0.015 & 10.00 & 6 \\
\hline Cambira & 2 & 0.012 & 5.26 & 8 & Perobal & 4 & 0.010 & 13.52 & 3 \\
\hline Campo Mourão & 29 & 0.038 & 6.33 & 8 & Pinhais & 3 & 0.049 & 0.48 & 0 \\
\hline Carlópolis & 25 & 0.055 & 35.28 & 2 & Pinhalão & 10 & 0.045 & 31.44 & 6 \\
\hline Cerro Azul & 64 & 0.048 & 72.94 & 6 & Porecatu & 3 & 0.010 & 4.30 & 6 \\
\hline Cianorte & 131 & 0.161 & 34.39 & 9 & Porto Rico & 4 & 0.018 & 28.75 & 11 \\
\hline Corumbataí do Sul & 2 & 0.012 & 10.58 & 6 & Realeza & 4 & 0.011 & 4.75 & 6 \\
\hline Cruzeiro do Sul & 4 & 0.015 & 17.38 & 3 & Rio Bom & 4 & 0.022 & 23.96 & 6 \\
\hline Curitiba & 9 & 0.021 & 0.09 & 1 & Rolândia & 5 & 0.011 & 1.61 & 4 \\
\hline Doutor Camargo & 30 & 0.254 & 100.36 & 2 & Sabaúdia & 2 & 0.011 & 6.17 & 4 \\
\hline Engenehiro Beltrão & 26 & 0.056 & 36.69 & 5 & Salto do Lontra & 3 & 0.010 & 4.18 & 4 \\
\hline Floresta & 6 & 0.038 & 18.86 & 2 & St. Amélia & 2 & 0.026 & 10.84 & 6 \\
\hline Foz do Iguaçu & 37 & 0.060 & 2.83 & 26 & St. Cecília do Pavão & 2 & 0.018 & 11.15 & 7 \\
\hline Francisco Beltrão & 8 & 0.011 & 1.88 & 4 & St. Izabel do Oeste & 4 & 0.012 & 5.73 & 3 \\
\hline Grandes Rios & 3 & 0.010 & 9.43 & 7 & St. Terezinha do Itaipu & 6 & 0.023 & 5.40 & 7 \\
\hline Guaíra & 28 & 0.050 & 17.41 & 12 & São Carlos do Ivaí & 6 & 0.027 & 18.00 & 2 \\
\hline Ibaiti & 10 & 0.011 & 6.61 & 7 & São Jerônimo da Serra & 21 & 0.025 & 36.65 & 12 \\
\hline Ibiporã & 9 & 0.030 & 3.49 & 4 & São Jorge do Ivaí & 48 & 0.136 & 170.79 & 3 \\
\hline Icaraíma & 39 & 0.058 & 90.32 & 4 & São Jorge do Patrocínio & 5 & 0.012 & 16.69 & 43 \\
\hline Indianópolis & 2 & 0.016 & 9.03 & 3 & São Manoel do Paraná & 1 & 0.010 & 9.27 & 14 \\
\hline Itambaraca & 12 & 0.058 & 35.28 & 2 & São Tomé & 19 & 0.087 & 68.04 & 12 \\
\hline Itaperuçu & 6 & 0.019 & 4.58 & 10 & Sarandi & 8 & 0.077 & 1.80 & 2 \\
\hline Ivaiporã & 7 & 0.016 & 4.32 & 3 & Siqueira Campos & 3 & 0.011 & 3.30 & 2 \\
\hline Ivatuba & 40 & 0.414 & 253.32 & 1 & Tapejara & 10 & 0.017 & 12.93 & 5 \\
\hline Jandaia do Sul & 3 & 0.016 & 2.86 & 9 & Terra Boa & 30 & 0.094 & 36.24 & 16 \\
\hline Japurá & 43 & 0.260 & 95.18 & 5 & Tomazina & 23 & 0.039 & 53.43 & 4 \\
\hline Jardim Alegre & 7 & 0.017 & 11.52 & 7 & Tuneiras do Oeste & 18 & 0.026 & 40.96 & 15 \\
\hline Jataizinho & 4 & 0.025 & 6.48 & 5 & Turvo & 9 & 0.010 & 13.07 & 20 \\
\hline Jussara & 73 & 0.346 & 212.27 & 10 & Umuarama & 80 & 0.065 & 15.00 & 6 \\
\hline Londrina & 75 & 0.045 & 2.78 & 11 & Uniflor & 1 & 0.011 & 7.80 & 3 \\
\hline Lunardelli & 3 & 0.015 & 11.75 & 14 & Total & 1356 & 0.042 & 28.81 & \\
\hline
\end{tabular}

NC: number of cases; V: natural vegetation covers (\%).

that is moderately or severely altered (Lima et al. 2002, Monteiro et al. 2008, Monteiro et al. 2009). No statistical significance $(p>0.05)$ was observed in terms of the vegetation factor per $\mathrm{km}^{2}$ and the percentage. Table II shows that Adrianópolis has 36\% residual vegetation, with a high DC (117.29), whereas the municipality of Jussara has only $10 \%$, with a high DC (212.27). Therefore, the life cycle of Leishmania is maintained regardless of the vegetation area in both the municipalities.

Although statistically significant difference was observed between the municipalities of Bandeirantes, Pinhalão, and Tomazina, which are included in the Cinzas- 


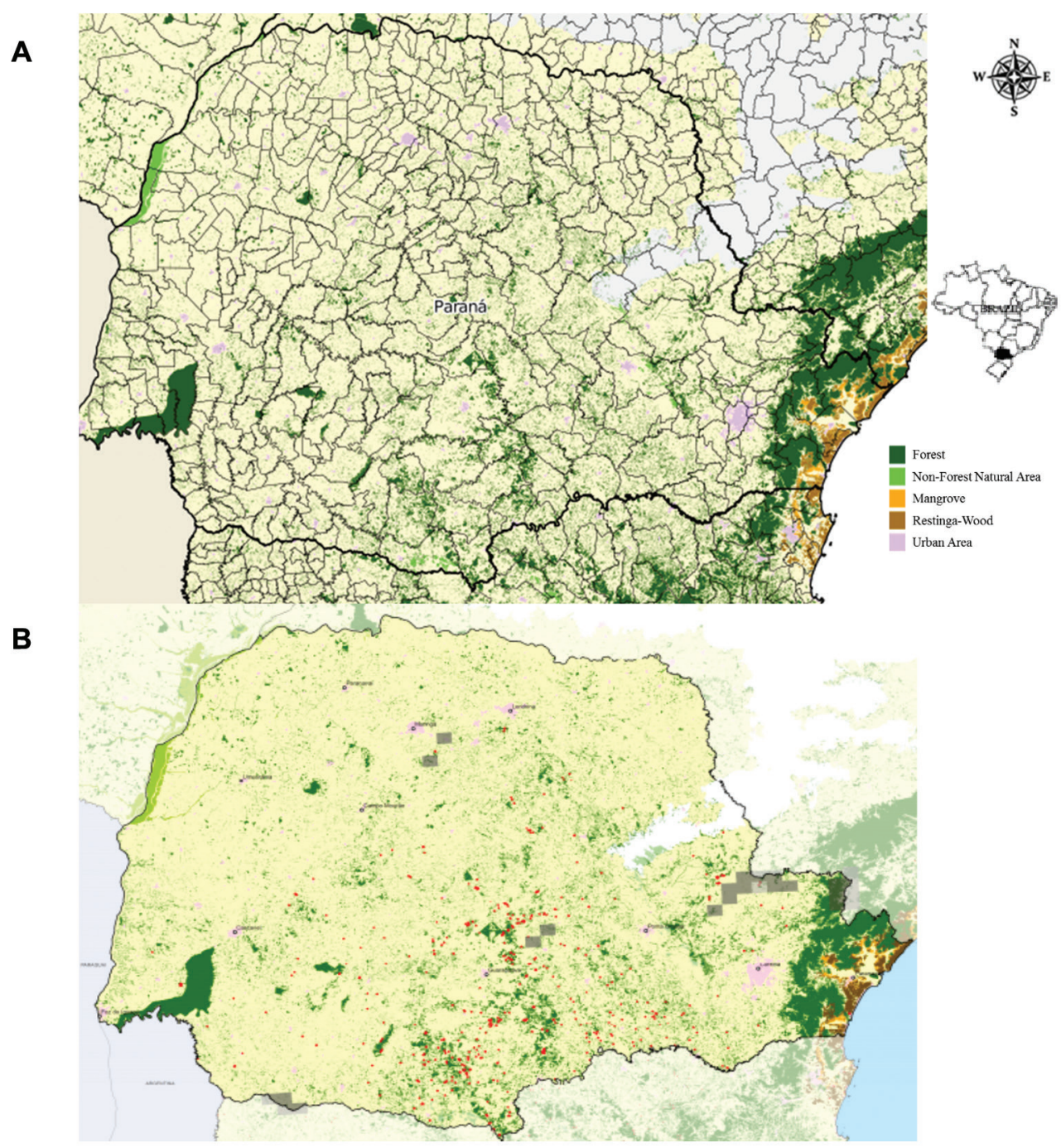

Fig. 3: residual vegetation cover in the state of Paraná from 2012 to 2013 (A) and from 2015 to 2016 (B) (SOSMA 2017).

Laranjinha CL hub, in terms of SD data $(\mathrm{p}<0.05)$ and natural vegetation cover (percentage and $\left.\mathrm{km}^{2}\right)(\mathrm{p}>0.05)$, these municipalities are located in the hydrography corridors of areas that are covered with semi-deciduous forest remnants, with conditions suitable for the transmission of Leishmania (Monteiro et al. 2009). The riparian forests are considered by the Brazilian Forest Code as a permanent preservation area, with several environmental functions and must respect an extension according to a river, lake, dam, or spring width. When damaged, the landowners must immediately restore the area. The situation is similar to that in the Tibagi hub, which includes the municipalities of Londrina and São Gerônimo da Serra, and a statistically significant difference was observed among these municipalities in term of SD data $(p<0.05)$ and natural vegetation cover factor $(p>0.05)$ (percentage).

In the Alto Ribeira hub, the municipalities of Adrianópolis and Cerro Azul, where the hydrography corridors exist, had statistically significant SD data $(\mathrm{p}<0.05)$ and vegetation factor $(\mathrm{p}>0.05)$ (per $\mathrm{km}^{2}$ and percentage). These corridors are covered by the Atlantic forest, which allows the coexistence of Leishmania, vectors, and reservoirs. The life cycle of Leishmania is maintained irrespective of the size of the natural vegetation that covers of the municipalities.

Although the municipalities with $\mathrm{SD}<0.010$ are not shown in Table II, all municipalities contribute in establishing the Paraná-Paranapanema and Ribeira circuits.

In the areas of the state of Paraná where the native vegetation was replaced by coffee crops in the 1930s and 1950 s as well as by soy, maize, or pasture crops more recently (Lima et al. 2002, Monteiro et al. 2008, Monteiro et al. 2009), domestic and wild animal infection due to Leishmania spp. (Lonardoni et al. 2006, Membrive et al. 2012, Truppel et al. 2014), the collection of sandflies in the residual forest areas (Luz et al. 2000, Teodoro et al. 2001, Massafera et al. 2005, Cella et al. 2011, Cruz et al. 2013) and recreational fishing activities (Lima et al. 2002) partly explain the higher incidence of CL cases in these areas. These studies in loco provide significant details about CL epidemiology. According to Marlow et al. (2013), air humidity, temperature, rainfall, and other 
environmental and climatic variables may influence CL incidence over the time variables investigated at Santa Catarina. However, these variables cannot be identified using the methodology used in the present study.

The SINAN data used in the georeferencing provided a broad coverage of the population in 399 municipalities in the state, which facilitates the future continuity of the longitudinal study of CL epidemiology in Paraná, to assist with the health surveillance. The professionals who participated in the surveillance must be trained to improve the completeness of the SINAN data because errors were still observed during the completion of the notification forms. However, the georeferencing instruments must be cautiously used because the enforcement of variables alone and other computational models, without considering the local factors that affect the exposed population and their habitat, and the association between them, can cause technicians, managers, and researchers to obtain inaccurate results in case of multifactorial diseases (particularly CL) (Lovelock 2010). Therefore, other local factors, such as the influence of the work of individuals in agrarian and urban spaces, migratory behavior, and vegetation cover, that may influence the risk factors for CL occurrence must be investigated. These factors can determine spatial distribution, thus contributing to the occurrence of this disease in endemic areas (Monteiro et al. 2009).

In conclusion - Due to the significant association between vegetation areas and the ecology of vectors and reservoirs of CL, these areas have a significant influence on the prevalence of the disease. Thus, concentration of LT cases are commonly reported in the production hubs of this disease, which are areas with native vegetation, such as riparian forests. However, vegetation is not the only factor that influences the incidence of CL. Other factors, such as temperature, rainfall, and floating population, may also affect the prevalence of the disease.

\section{AUTHORS' CONTRIBUTION}

HAM and UE formulated the study and wrote the manuscript; DFR contributed to the statistical analyses. All authors read and approved the final manuscript.

\section{REFERENCES}

Bivand RS, Pebesma E, Gómez-Rubio V. Applied spatial data Analysis with R. 1. New York: Springer-Verlag New York; 2008.

Cella W, Melo SCCSD, Legriffon CMDO, Freitas JSD, Kuhl JB, Teodoro U, et al. Sandflies in rural localities in northwest Paraná state, Brazil. Cad Saude Publica. 2011; 27(12): 2461-68.

Cruz CFR, Cruz MFR, Galati EAB. Sandflies (Diptera: Psychodidae) in rural and urban environments in an endemic area of cutaneous leishmaniasis in southern Brazil. Mem Inst Oswaldo Cruz. 2013; 108(3): 303-11.

Development Core Team. R: a language and environment for statistical computing. 2014.

Eisen RJ, Eisen L. Spatial modeling of human risk of exposure to vector-borne pathogens based on epidemiological versus arthropod vector data. J Med Entomol. 2008; 45(2): 181-92.

IAPAR - Instituto Agronômico do Paraná. Cartas climáticas do Paraná. 2002. Available from: http://www.iapar.br/modules/conteudo/conteudo.php?conteudo $=677$.
IBGE - Instituto Brasileiro de Geografia e Estatística. Censo Demográfico. 2010. [Internet]; cited 2016, March 01. Available from: http://www.ibge.gov.br/estadosat/perfil.php?sigla=pr.

IBGE - Instituto Brasileiro de Geografia e Estatística. Estimativas populacionais. [Internet]; cited 2016, March 01. Available from: http://www.ibge.gov.br/estadosat/perfil.php?sigla=pr.

King RJ, Campbell-Lendrum DH, Davies CR. Predicting geographic variation in cutaneous leishmaniasis, Colombia. Emerg Infect Dis. 2004; 10(4): 598-607.

Lima AP, Minelli L, Teodoro U, Comunello E. Tegumentary leishmaniasis distribution by satellite remote sensing imagery, in Paraná state, Brazil. An Bras Dermatol. 2002; 77(7): 681-92.

Lonardoni MVC, Silveira TGV, Alves WA, Maia-Elkhoury ANS, Membrive UA, Membrive NA, et al. Human and canine American cutaneous leishmaniasis in Mariluz, Paraná state, Brazil. Cad Saude Publica. 2006; 22(12): 2713-16.

Lovelock J. Gaia: alerta final. Rio de Janeiro: Intrínseca; 2010. 264 pp.

Luz E, Membrive N, Castro EA, Dereure J, Pratlong F, Dedet JA, et al. Lutzomyia whitmani (Diptera: Psychodidae) as vector of Leishmania (V.) braziliensis in Parana state, southern Brazil. Ann Trop Med Parasitol. 2000; 94(6): 623-31.

Maack R. Geografia física do estado do Paraná. Curitiba: Banco de Desenvolvimento do Paraná; 1968.

Magalhães GBO. The use of geoprocessing and statistic in ecological studies of epidemiology: the case of dengue in 2008 in the metropolitan area of Fortaleza. Hygeia. 2012; 8(15): 63-77.

Marlow MA, da Silva MM, Makowiecky ME, Eger I, Rossetto AL, Grisard EC, et al. Divergent profile of emerging cutaneous leishmaniasis in subtropical Brazil: new endemic areas in the southern frontier. PLoS One. 2013; 8(2): e56177.

Massafera R, Silva AM, Carvalho AP, Santos DR, Galati EAB, Teodoro U. Phlebotomine sandflies of southern Brazil. Rev Saude Publica. 2005; 39(4): 571-7.

Medronho RDA, Valencia LIO, Fortes BDPMD, Braga RCC, Ribeiro SDV. Spatial analysis of hepatitis A seroprevalence in children of a poor region of Duque de Caxias, Rio de Janeiro, Brazil. Rev Bras Epidemiol. 2003; 6(4): 328-34.

Membrive NA, Rodrigues G, Gualda KP, Bernal MVZ, Oliveira DM, Lonardoni MVC, et al. Environmental and animal characteristics as factors associated with American cutaneous leishmaniasis in rural locations with presence of dogs, Brazil. PLoS One. 2012; 7(11): e47050.

Monteiro WM, Neitzke HC, Lonardoni MVC, Silveira TGV, Ferreira MEMC, Teodoro U. Geographic distribution and epidemiological features of American tegumentary leishmaniasis in old rural settlements in Paraná state, southern Brazil. Cad Saude Publica. 2008; 24(6): 1291-303.

Monteiro WM, Neitzke HC, Silveira TGV, Lonardoni MVC, Teodoro U, Ferreira MEMC. Poles of American tegumentary leishmaniasis production in northern Paraná state, Brazil. Cad Saude Publica. $2009 ; 25(5)$ : 1083-92.

MS - Ministério da Saúde. Guia de vigilância em saúde. 2016. Available from: http://portalarquivos2.saude.gov.br/images/pdf/2016/ agosto/25/GVS-online.pdf.

MS - Ministério da Saúde. Leishmaniose tegumentar americana - distribuição de casos confirmados de LTA de 1980 a 2005. [Internet]; cited 2017, January 15. Available from: https://goo.gl/mltzTz.

SOSMA - Fundação SOS Mata Atlântica. Atlas e estatística dos remanescentes florestais. [Internet]; cited 2017, January 15. Available from: https://www.sosma.org.br/projeto/atlas-da-mata-atlantica/ dados-mais-recentes/. 
Teodoro U, Kühl JB, Rodrigues M, Santos ES, Santos DR, Maróstica LMF. Phlebotomines collected in remaining forests and wild animal shelters in zoological garden in the urban area of Maringá, Paraná state, southern Brazil. Preliminary study. Rev Soc Bras Med Trop. 1998; 31(6): 517-22.

Teodoro U, Silveira TGV, Santos DR, Santos ES, Santos AR, Oliveira $\mathrm{O}$, et al. Frequency of phlebotomine fauna at home and in domestic shelters in the peridomicile, in the municipalities of Cianorte and Doutor Camargo - state of Paraná - Brazil. Rev Pat Trop. 2001; 30(2): 209-23.

Truppel JH, Otomura F, Teodoro U, Massafera R, Costa-Ribeiro $\mathrm{MCV}$, Catarino CM, et al. Can equids be a reservoir of Leishmania braziliensis in endemic areas? PLoS One. 2014; 9(4): e93731.

WHO - World Health Organization. Leishmaniasis. 2017. Available from: http://www.who.int/leishmaniasis/en/. 